ROCZNIKI HUMANISTYCZNE

Tom LXVIII, zeszyt $11-2020$

DOI: https://doi.org/10.18290/rh206811-3

ANNA BLOCH-ROZMEJ

\title{
THE PLACE OF THE ROMANI LANGUAGE AND CULTURE IN POLAND: QUESTIONNAIRE-BASED INSIGHTS
}

\begin{abstract}
A b stract. This article presents an overview of the Romani culture and language in Poland and discusses the results of the Romani-related research in the form of an online questionnaire addressed to Poles. The first opening sections of the paper constitute an introduction into the world of Roms - their history, lifestyle and major elements of culture. We also include a brief description of Romani which, as an Indo-Aryan language, is very different from Polish.

The aim of the research we describe was to determine the prevalent attitudes of Poles towards the Romani community and discover how much Polish people know about Roms. It was also our intention to identify the existing stereotypes of Gypsies and their possible sources. We hope that our research findings will support endeavors to improve Polish-Romani relations and abolish the stereotypes that upset the peaceful cohabitation of the two communities. We also subscribe to the view that cultural diversity should be both protected and popularized as it contributes to the cultural heritage of Europe.
\end{abstract}

Keywords: Romani; culture; language; attitudes; stereotypes.

\section{INTRODUCTION}

The aim of this article is to present a brief introduction to the issues of the Romani language and culture and determine the prevalent attitudes towards the Romani community in Poland. To this end, a special questionnaire was designed and administered on March 13-31, 2020. Its results will enable us to gain a deeper insight into the problem, formulate some conclusions concerning Poles' attitudes and sources of the existing stereotypes. I hope my findings will be useful for future research related to the culture of the Romani people in Poland.

AnNa Bloch-RozmeJ, PhD, Habil., Head of the Department of Applied Linguistics, The John Paul II Catholic University of Lublin; address for correspondence: Al. Racławickie 14, 20-950 Lublin, Poland; e-mail: anna.bloch-rozmej@kul.pl; ORCID: https://orcid.org/0000-0001-8675-1726. 
The article is organized as follows. We begin with a brief outline of the history of the Polish-Romani relations and report on the basic facts concerning the Romani community in Poland. Further, we shall focus on the characteristics of the Romani language and in particular its varieties spoken on the territory of Poland. The theoretical part of the paper will also include a concise note on the major elements of the Romani culture, especially those that Poles are most likely to encounter in their everyday contacts with Roms.

In the research section of the article, we discuss the results of the online survey designed and administered for the purpose of this study. The intention of the conducted research was to broaden our understanding of the attitudes of Polish people towards Roms themselves as well as their language and culture. We believe that specific answers to some of the questions of the survey will shed some light on the potential causes of intercommunity tensions and misconceptions that interfere with possible benefits of mutual cultural enrichment.

\section{THE ROMANI COMMUNITY IN POLAND}

The available sources on the Romani indicate that first Roms lived in northwestern India from which their migration to Asia and Europe began. Although Roms have settled in most parts of Europe, North and South Americas, and Turkey, the largest community of Romani speakers live in the Balkan Peninsula (Matras 222). Ethnographic, historical, and linguistic research findings have greatly broadened our knowledge of the origins and history of the Romani people. It is now recognized that from India they migrated to Persia, which is substantiated by numerous Persian borrowings in Romani as well as certain mentions of the people in the literature of that time (e.g., Shahnameh: The Persian Book of Kings). On their way to Europe, Roms travelled through Armenia and the Byzantine Empire. It was in that period that the Gypsy-specific model of culture developed. Thus, Roms would adopt many local elements of culture but the community-internal social structure precluded the possibility of their total assimilation or loss of identity. The migrating Roms were always perceived as strangers. In the sixteenth century, there was no part of Europe that they would not have reached. Europe, in fact, became a sort of "fatherland" for the majority of Roms. Beyond doubt, it has played the crucial role in the history of the people, shaping their laws and traditions. 
In Poland, Roms arrived in the fourteenth century. The available sources reveal that their situation was much better here than in many other European countries. They did not have to fear any persecution or repressive measures. Even though in the sixteenth century some banishment acts were issued against them, they were not enforced. In the middle of the seventeenth century, the royal office set up the institution of the head of the Roma. The treatment of Roms by the authorities worsened after Poland had fallen victim to the partitions in the eighteenth century and lost its independence. It was then that the time of violence and persecution against Roms began. Some of the sanctions involved the ban on the use of Romani, possession of horses, migration or even wearing colorful clothes. In the Second Polish Republic, the question of Romani people was officially treated as rather marginal. In the years 1918-1939, the Romani-Polish relations were characterized by numerous social conflicts, especially in villages and small towns. The times of oppression, when Poland was partitioned, led to Roms' hostility towards the state. However, it was also at that time that Romani people got more engaged in political, educational, and artistic activity. Also, Polish artists and journalists got interested in the life of the Gypsies. Some Roms wanted to integrate themselves with the Polish society. Many served in the army, for instance, in the elite regiment of uhlans, which earned them social respect.

When Poland was under a communist regime, the authorities tried to curb the migratory lifestyle of Roms. Consequently, many of them were forced to settle down (Krzyżanowski 13). The discriminatory measures undertaken by the communists, to a large extent, suppressed the migration of the Gypsies. It has to be noted that Roms' ethnic and cultural diversity was perceived as unwelcome by the authorities whose aim was to create a mono-national state. However, perseverance and courage of the Romani people enabled them to retain their independence and cultural identity.

When Poland regained full independence in 1989, i.e., after communism had been abolished in Central and Eastern Europe, the official policy of enforced assimilation was replaced by one encouraging the integration of the Gypsies and respectful of their otherness. In fact, cultural diversity came to be regarded as an enrichment of the European cultural heritage. Over the last decades, the contribution of Roms to the economic, social and cultural life of Polish society has been constantly increasing. Also, the situation of the very minority has been marked by many positive changes. More and more Romani children attend school, many Roms continue their education and actively promote the Romani culture and language in numerous organizations and associations. 
Today, the number of the Romani people on the Polish territory is difficult to estimate. Hence, the estimates range from 20,000, as indicated in official documents (www.mswia.gov.pl) to 30,000-the number reported by different Romani associations. The formal status of Roms is regulated by the Act of National and Ethnic Minorities and on the Regional Language of 2005, whereby Roms are regarded as an ethnic minority.

At present, we there are four major groups of Romani people living in Poland:

- Polska Roma, present in Poland since the fifteenth century, with a migratory lifestyle until the 1960s, cultivating the Gypsy traditions;

- Bergitka Roma, originally living in southern Poland (Beskidy and Podhale), who after World War II migrated to northern and western Poland to settle there. They have lost many traditions connected with the migratory lifestyle.

- Lovari and Kalderash, present in Poland since the 1870s, who migrated into Poland from Siedmiogród and Wołoszczyzna.

The Roms belonging to the Polska Roma, Lovari and Kalderash groups have shaped their traditions based on Romanipen, the unwritten code of Gypsy laws and taboo-related restrictions. Since the very beginning of their history, Roms have orally transmitted their culture, moral and ethical norms of behavior, language and laws of conduct.

\section{THE ROMANI LANGUAGE}

Romani čhib is a label that refers to the language of Roms and a cover term for a variety of its dialects. The Romani language, classified by Wagner as an Indo-Aryan language, is spoken in most parts of Europe, both Americas and Turkey (2). In fact, Romani is the only indigenous Indo-Aryan language spoken in Europe. The language developed from Sanskrit. The Indian origins of the language are substantiated by many of its lexical and grammatical properties (4). One of its major varieties called Vlax is spoken in Ukraine, southern Russia, the Balkan countries, Greece, Turkey, Hungary, and in Slovakia (Boretzky 1). As noted in Boretzky, the Vlax dialect can be divided into a northern (mainly Romanian or non-Balkan) group and a southern one (in the Balkans outside Romania) (90). Within the northern group, we can distinguish a Hungarian-dominated (western) branch and a less homogeneous eastern group (Boretzky 97). The speakers of the former dialect who call themselves Lovára 
(sg. Lovári), live in the area of the former Austrian-Hungarian monarchy and the neighboring regions including Germany and southern Poland.

It is noteworthy that Romani is a cover term to refer to a group of dialects since the language does not have any standardized form. This lack of standard Romani generates problems in communication even between communities living close to each other in terms of geographical location. The differences among dialects are structural, phonetic, and lexical. The dialects spoken on the territory of Poland include: Polscy Cyganie Wyżynni, Wurdonara Roma, Polska Roma, Vlax (Lovari, Kalderash [Kalderasze]), and Bergitka Roma. Below, see a sample of Polska Roma transliterated in Polish - the prayer Our Father (see the Polish-language version of Wikipedia under "Język romski"): ${ }^{1}$

Jamaro Dad,

Sawo san dre bolipen,

Swanto Tyro ław,

Te jaweł Tyro chułajiben,

Te kanden Tyre ława,

Adźia dre bolipen, syr pe phuw.

De jamenge sodywesuno maro dadywes,

Odmek jamenge jamare użlipena,

Syr jame odmekas jamare użłenge,

Na lidżiuw jamen chyria dromenca,

Rakh jamen tugendyr.

Amen

As regards the history of linguistic research on Romani, Crofton argues that the first 13 sentences of Romani were published in 1542 in the work by Andrew Borde titled Egipt speche (quoted in Matras 2) and accompanied by their English translations. Later, in 1570, in the manuscript by Johan van Ewsum, Clene Gijpta Sprake, 53 Romani words and phrases were listed, together with their Low German glosses. Matras further maintains that the next source containing Romani words was De Nubianis erronibus, quos Itali Cingaros appellant, eorumque lingua (1597) by Bonaventura Vulcanius (2). In 1668, Evliya Celebi collected further vocabulary samples and 21 sentences which were published in his Seyahat-name and translated into Ottoman Turkish. As Kluge notes, 38 Romani words also appeared in 1691 in Job Ludolf's

\footnotetext{
${ }^{1}$ The four major dialects indicated by the website Dziedzictwo językowe Rzeczypospolitej: Baza dokumentacji zagrożonych języków ("Romskie dialekty/Romani”) are: Polska Roma, Bergitka Roma, Kalderari/Kałderasze [Kalderash], and Lowari [Lovari].
} 
wordlist (185-90). We owe the first linguistic description of the Romani grammar to Johann Rüdiger who in 1777 classified the language to the IndoAryan group and compared Romani to Hindustani (Matras 2). The first etymological dictionary and a comparative grammar of Romani was written by August Pott in 1844-1855. The work was based on the descriptions of a number of Romani dialects spoken in Europe. Matras argues that Pott's work "remains the only monograph so far published that is devoted to a comparative and historical discussion of Romani as a whole" (3). The two other valuable sources focusing on the Romani language are the Journal of the Gypsy Lore Society (1888-; since 2000 under the name Romani Studies) and John Sampson's Dialect of the Gypsies of Wales (1926).

The range of linguistic issues related to the Romani language was considerably extended after World War II to include such problems as language status, contact and language planning, grammar, discourse, and typology. This drift away from the previous concentration on etymological and comparative issues was closely connected with an increase of Romani political and cultural activism. The political and social changes that took place in Eastern and Central Europe, after the fall of communism, stirred up interest in Romani. In the years 1990-2000, many Romani-focused monographs and articles appeared. These scientific endeavors were often supported by governments promoting the idea of cultural diversity in Europe. Recently, many researchers of Romani origin conduct Romani-based studies. However, the majority of linguists doing research on Romani are not Roms.

Beyond doubt, apart from the obvious scientific benefits, research on Romani has at least a few more important advantages. It certainly greatly supports language education-related activity and contributes to language planning. We can also be hopeful that solid linguistic facts determined through linguistic investigation will eventually replace stereotypes of Roms, so deeply rooted in the societies in which Romani communities live today. The present paper also subscribes to the view that culture-related investigation will help us gain valuable insights in the ways in which Romani people contribute to the cultural heritage of Europe. To this end, in the subsequent section, a brief characteristics of Gypsy laws and traditions will be provided. 


\section{ROMANI CULTURE IN POLAND}

The Romani culture is in many respects exceptional. It is not based on literature or architecture. Their group identity is closely connected with their migratory lifestyle, which has determined a specific philosophy of life, social norms, and rites. Traditionally, Roms would choose occupations connected with trade, craft, entertainment, and fortune telling. In the past, Gypsies were regarded as good locksmiths, blacksmiths, and carpenters. Many of them were circus performers and jugglers. With time, many of these professions have disappeared, and currently the ones that have remained are connected with trade and music. We can still hear Gypsy music during concerts, festivals and wedding receptions.

The unwritten law of the Romani people is the central element of the cultural life of the community (Ficowski 179-184). Roms' traditional social structure is of patriarchal character (Mirga and Mróz 131). In a Romani family, the most important figure is the father, who is subordinated to the leader of the kin. Their most significant duty is to make sure that the rules of Romanipen are obeyed. Romanipen is a complex set of rules, traditions, rites and beliefs that regulate social relations within a community, assign specific roles and define obligations and rights of individuals. One of its basic requirements is a migratory lifestyle. It also demands that the Romani identity should be manifested both within and outside of the community. One form of this manifestation is the use of the Romani language. Importantly, Roma may not be taught to non-Roms. Romanipen assumes that Roms show solidarity towards other members of their community, respect and cultivate traditions and Romani rites. This strengthens the unity of the group. Breaking any law of Romanipen results in defilement (mageripen). The concept of mageripen underlies the distinction between what is pure and what is defiled. This division applies to behavior, space, time, and things. Thus, the lower part of the body is distinct from the upper part, body-internal reality is distinct from body-external, and Roms from non-Roms. Purity and defilement are also crucial in determining the value of kinds of food, hygiene rituals, gender, age, as well as regulating the functioning of the Romani community in a given society (Kowarska 29-32). Defilement, which can be either small (Tykne mageripena) or big (Bare mageripena), leads to the exclusion of a person from the community, either temporary or permanent, respectively. Compared to men, women have an inferior status, which derives from the fact that they 
are believed to be frequently defiled. There are many restrictions imposed on women, both in terms of behavior and appearance.

As regards religion, different Romani groups hold different religious beliefs, depending on the dominant religion in a particular country. Consequently, Roms living in Poland are Catholics, those living in Germany are Protestants and Muslims when living in Albania. Roms also believe in magic and supernatural powers, spells that bring good fortune, amulets and talismans, curses and healing rituals. They fear demons that persecute people who did harm to others. According to some beliefs, dead people can come back to life in someone else's body or live as animals. Roms have their Catholic patron saint-Black Sara (Kali Sara).

The Romani culture is very different from that of Poland; this fact has been the source of much controversy. Throughout centuries, the Romani traditions and beliefs have been either admired or criticized. Roms have exerted a considerable influence on the Polish literature, painting, and cinematography. Importantly, the image of a Gypsy presented in works of art is significantly different from the one that functions in the society. The latter is often that of a thief, beggar, or a victim of prejudice. What Poles cannot typically tolerate is the Gypsy family model, too young brides, illiteracy, or the lack of stable income. Such an attitude has inspired mutual hostility. Recently, Polish-Romani relations have been significantly transformed. Since the law of obligatory settlement was imposed, Roms have adapted to the rules regulating the life of the society they are part of. Nowadays they learn from their Polish neighbors everything that is likely to make their life better. Yet, as argued by Kopańska, Poles have problems with treating Roms as Polish citizens (139).

\section{ROMS AND THE ROMANI LANGUAGE AND CULTURE IN THE EYES OF POLES}

\subsection{Research aims and tools}

This section reports on the research on the perception of Roms, their language and culture by Poles. The tool we chose to implement was an online questionnaire administered between March 13 and March 31, 2020. The survey was created using docs.google.com forms and was made available at https:// docs.google.com/forms/d/e/1FAIpQLSd0HEtX0NOmAoZOSHXmx6TAjrQTXv 12DAVo1mvJTqG4AG9qew/viewform?usp=sf_link. 
It was addressed to Facebook users as a public post, specific Facebook groups, students of English Philology and teachers of English working in the Department of English Studies at the John Paul II Catholic University of Lublin. The initial number of addressees amounted to 1,500. Yet, the potential number of addressees was much higher since Facebook users were asked to share the questionnaire with their acquaintances. The data were collected for over two weeks. The total number of responses was 150 , which constitutes only a fraction of the potential respondents. The rationale behind this particular choice of the research tool rests on the awareness that modern technology enables us to reach respondents of different age, professions, social and economic background and with varied education experience. It must be emphasized that reaching the widest possible range of respondents representing the widest spectrum of views on the problem was the major aim of the research. It also needs to be added that personal contact with potential respondents was impossible due to the coronavirus epidemics which was spreading at the time of the survey. Its major aims were threefold: a) to examine Poles' knowledge of Roms, their language and culture; b) to examine Poles' attitudes towards Roms, the Romani language, and culture; and c) to identify the existing stereotypes and their sources.

The language of the questionnaire was Polish although we believe that the majority of the respondents were English language users. We assumed that personal attitudes and beliefs would be most precisely expressed in one's native language. It was also predicted that the level of respondents' anxiety would be lower, thus raising the probability of their filling in the questionnaire. The survey consisted of 22 questions and the time it would take was between 3 and 10 minutes. Five concerned the respondent's gender, age, profession, education, and place of residence. The remaining questions were related to Roms, their language and culture.

In the subsequent section, the results of the survey will be provided. We shall present the answers to the questions in the form of graphs and include brief summaries of the responses. Further, the research outcomes will be subject to detailed analysis. Finally, we shall try to formulate conclusions concerning Poles' views on the Romani-related issues.

\subsection{Research results}

As pointed out above, the five opening questions of the survey pertained to the respondents' personal data, including gender, age, profession, education, 
and place of residence. $70.5 \%$ of the respondents were women, and $29.5 \%$ were men. A similar percentage of the questionnaire addressees $(73.2 \%)$ were between 19 and 30 years of age. The second largest age group is that of 31-50 (see the group age profile in fig. 1).

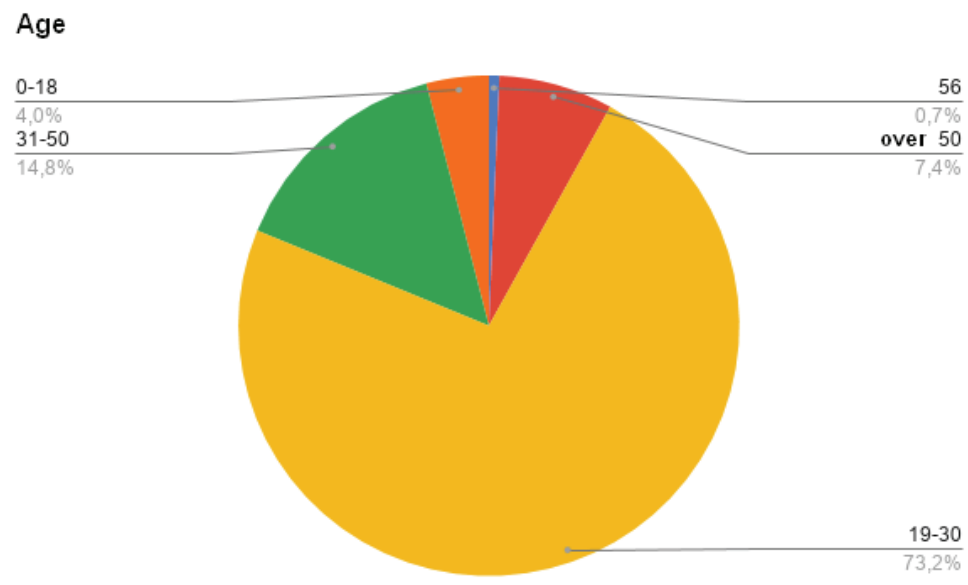

Fig. 1. Age of the respondents.

The respondents represent various professions; however, the number of students is considerable, which is an expected consequence of addressing the survey to numerous groups of young people who, in turn, shared the questionnaire with their friends and colleagues. Hence, the results of the survey can be treated as some sort of prognostic for future changes in people's attitudes towards Roms and their culture.

In terms of educational status, the respondents can be almost equally divided into two groups: those having higher education $(49.7 \%)$ and those with secondary education (49\%). The yellow section represents the proportion of respondents with primary education (see fig. 2). 


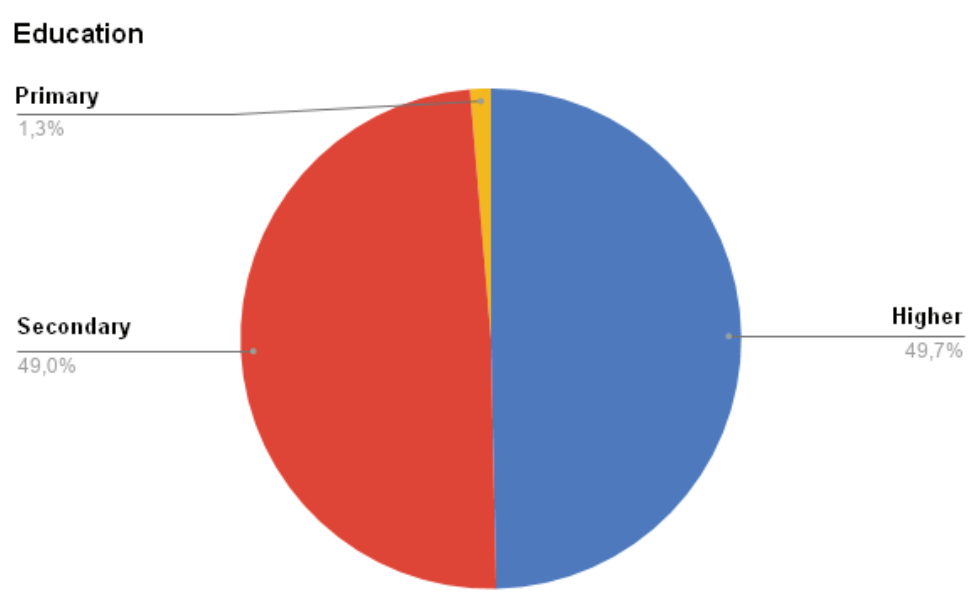

Fig. 2. Education of the respondents.

As for place of residence, the majority of the respondents (52.3\%) live in cities with a population exceeding 100 thousand inhabitants (red), 18.8\% come from villages, and $28.9 \%$ live in towns (fig. 3 ).

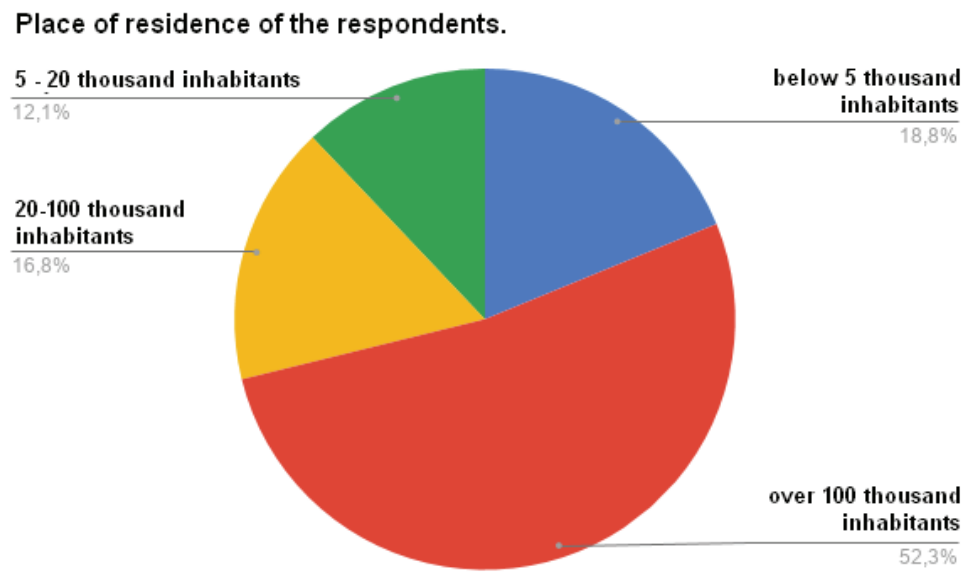

Fig. 3. Place of residence of the respondents.

Concluding this introductory section of the survey, it needs to be stressed that the majority of the respondents are either young or middle-aged, relatively well-educated and living in bigger cities. The remaining questions of the survey pertain to the knowledge of and attitudes towards the Romani people, their lan- 
guage and culture. This part of the questionnaire starts with the question about sources of the respondents' knowledge of the Romani community. We provided six possible options to choose from (from top to bottom): "Own experience/Family members' and friends' stories/Internet/Literature/Media/I have no knowledge of the Romani people," including the option "Other." The answers provided can be graphically depicted as follows (fig. 4).

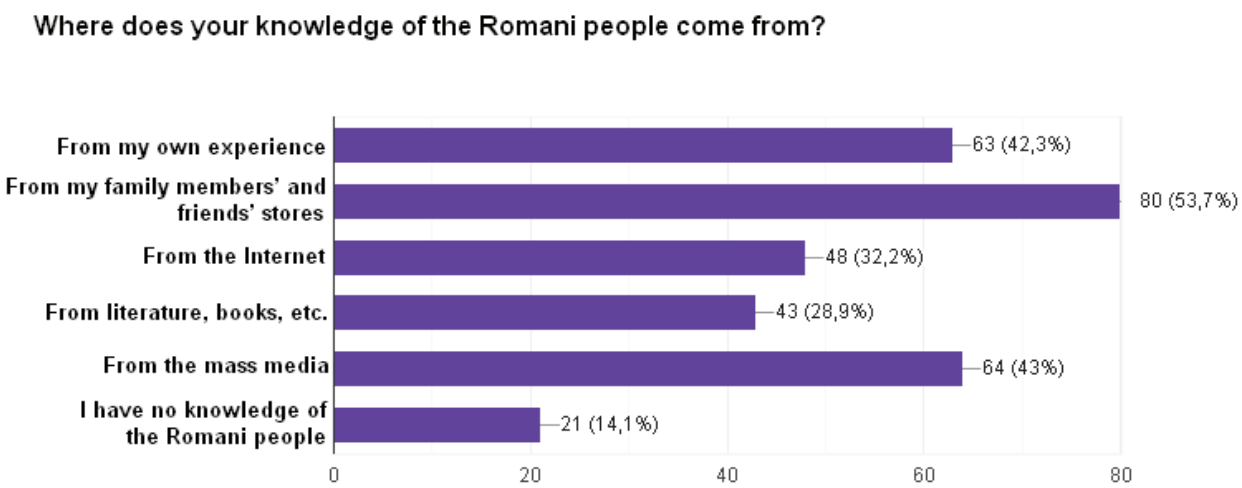

Fig. 4. Question 6: Where does your knowledge of the Romani people come from?

Here, the respondents were allowed to choose more than one answer. Thus, the largest number of the sampled group (53.7\%) acquired the knowledge of Roms and Romani-related issues from their relatives and acquaintances. Equally numerous groups drew their knowledge from personal experiences and information provided by the media ( 42.3 and $43 \%$, respectively). Internet sources were indicated by $32.2 \%$ of the respondents, books, and literature by $28.9 \%$, whereas $14.1 \%$ declared that they had no knowledge of either Roms or Romani culture.

Our next question concerned the size of the Romani community in Poland. We wanted to find out how the respondents estimated the percentage of Roms living in Poland (fig. 5). 


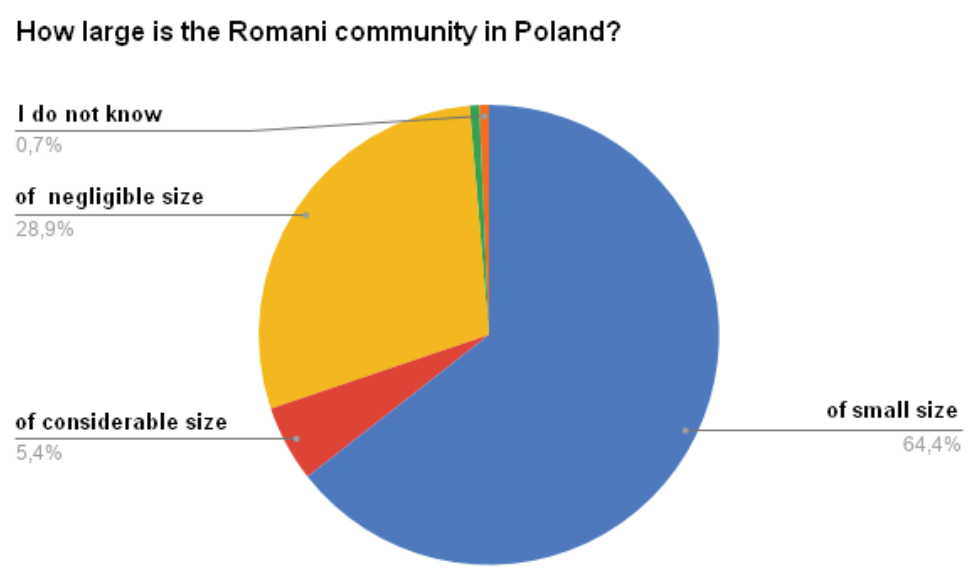

Fig. 5. Question 7: How large is the Romani community in Poland?

As illustrated above, a vast majority of the respondents (blue) estimate the percentage of the Romani citizens of Poland as small $(64.4 \%) ; 28.9 \%$ perceive it as negligible, and only $5.4 \%$ think that Roms constitute a considerable number of Polish citizens (red).

The next question asked if they knew where in Poland the largest communities of Roms can be found. $52.3 \%$ of the respondents answered "No, I don't" (yellow), 34.2\% admitted that they knew some of these areas, while $11.4 \%$ said "Presumably yes"; only 3 respondents (blue) said they had precise knowledge of the subject (fig. 6).

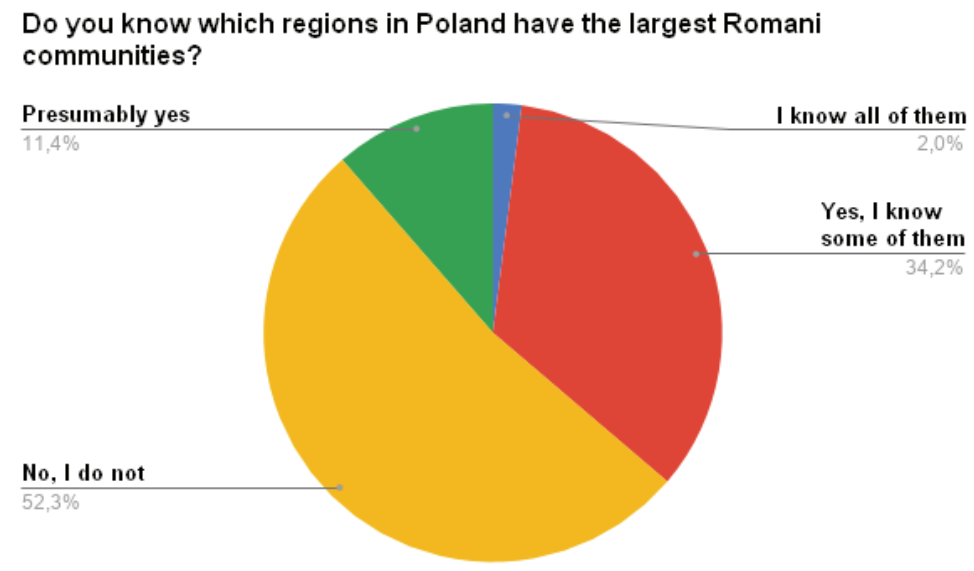

Fig. 6. Question 8: Do you know which regions in Poland have the largest Romani communities? 
Then, we asked the respondents about their personal contacts with Romani people (fig. 7).

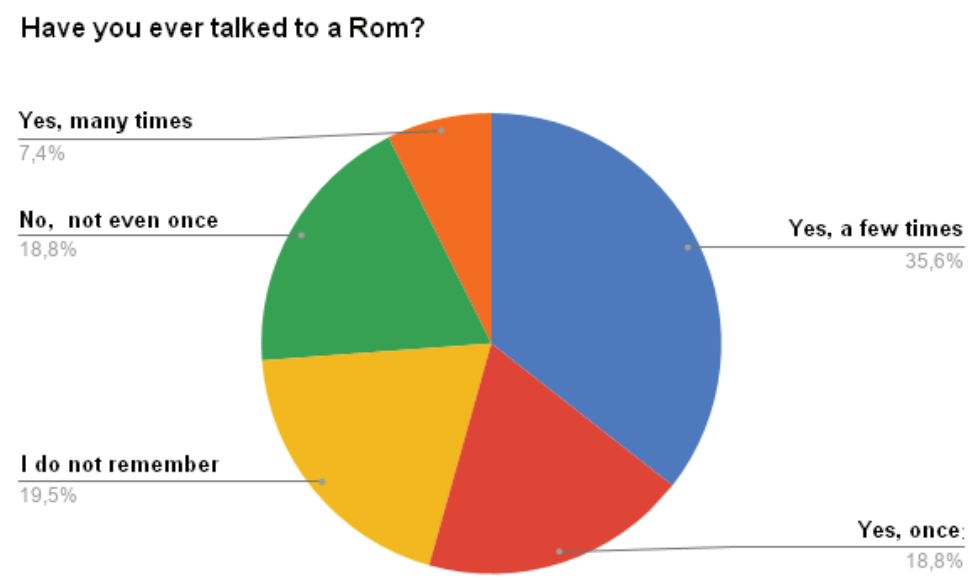

Fig. 7. Question 9: Have you ever talked to a Rom?

Almost one fifth of the respondents (18.8\%) had never talked to a Rom (green), while $19.5 \%$ did not recall having had such a conversation (yellow). $18.8 \%$ of the sampled group had talked to a Rom once and as many as $35.6 \%$ remembered having had a couple of linguistic exchanges (blue). Frequent linguistic contact with Romani-speaking people was declared by $7.4 \%$ of the respondents. As for the kind of conversation that the respondents had, a response to a fortune-telling proposal turned out to be the most frequent choice $(40.3 \%)$. Next came a friendly conversation (22.8\%), a traditional greeting $(16.1 \%)$, an argument (5.4\%), and an academic discussion $(2.7 \%)$. Those who chose the option "Other" indicated a conversation concerning the topic of education, participation in fortune-telling, a conversation at work and at a school meeting, each mentioned by a single person.

Another question of our survey was focused on the respondents' experiences involving the Romani language (fig. 8). 


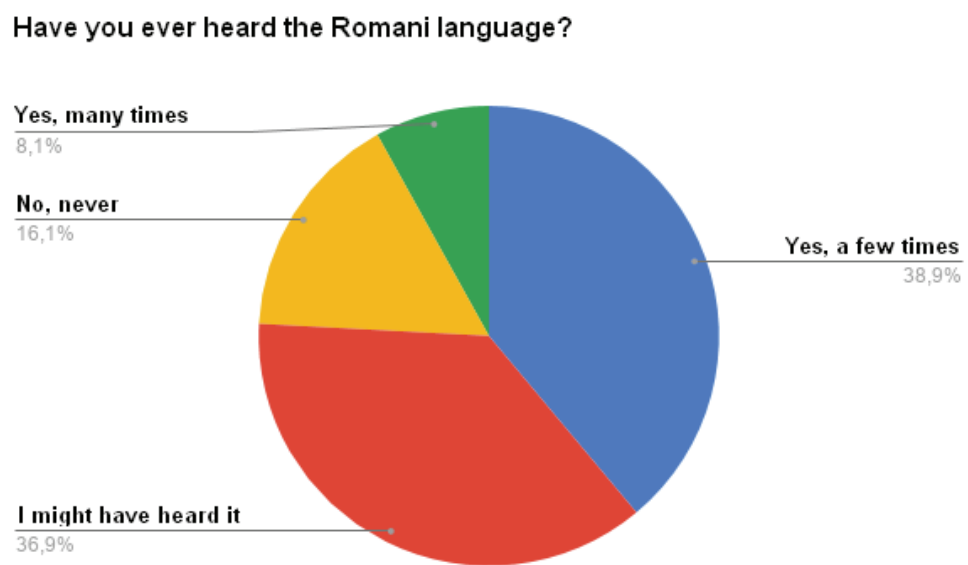

Fig. 8. Question 11: Have you ever heard the Romani language?

There were six options to choose from. These included: "Yes, many times" (8.1\%); "Yes, a few times," selected by as many as $38.9 \%$ (blue); "Never" (16.1\%); and "Perhaps, but I did not realize that it was Romani that I heard," chosen by $36.9 \%$ (red). We also wanted to know what other languages they thought Romani resembles (see fig. 9).

What other language do you think Romani is similar to?

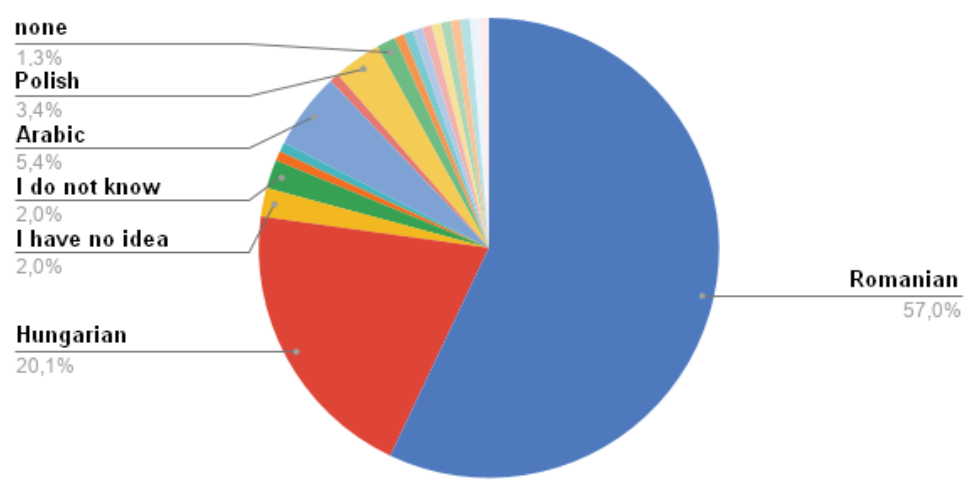

Fig. 9. Question 12: What other language do you think Romani is similar to? 
The languages mentioned by the respondents included Hungarian, Romanian, Polish, Arabic, Sanskrit, and Turkish. The prevailing majority of the participants chose Romanian (57\%), and the second most popular response was Hungarian (20.1\%). 3.4\% considered Romani similar to Polish (light yellow), and $5.4 \%$ to Arabic (light blue). We were also interested whether Polish people knew any Romani words of phrases. Out of the 150 respondents, only a few gave examples of Romani words. The words mentioned were szoa, siaba daba, and Jawen saste.

Question 14 of the survey concerned the contribution of Roms to the Polish culture (fig. 10).

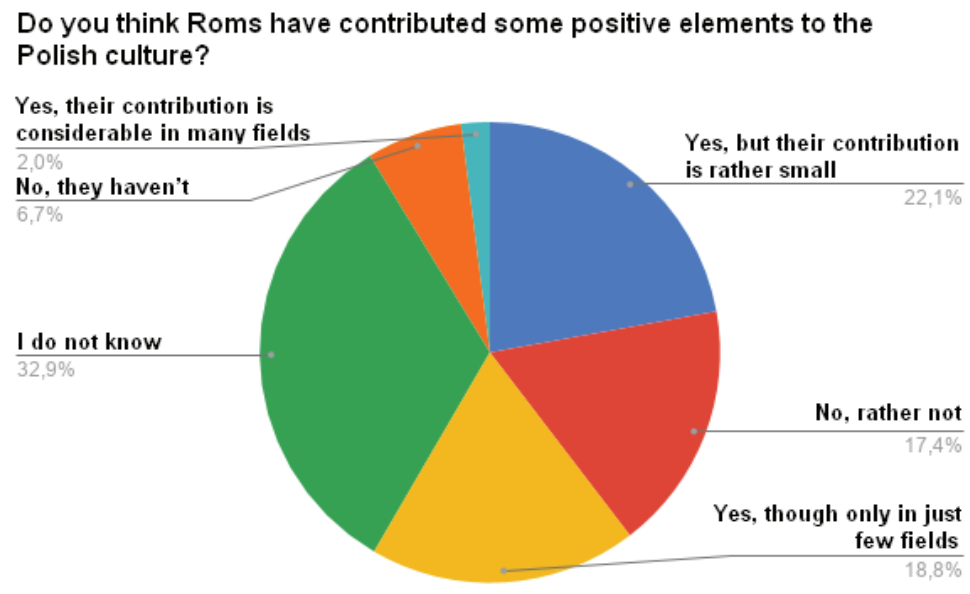

Fig. 10. Question 14: Do you think Roms have contributed some positive elements to the Polish culture?

$32.9 \%$ of the respondents confessed they had no sufficient knowledge to be able to answer this question (green). 18.8\% thought that they did but in just few areas (yellow). 22.1\% consider Roms' contribution as rather small. The overall number of the answers "No" and "Not really" was $24.1 \%$. Only $2 \%$ of the respondents regarded this contribution as considerable in many areas.

Further, we enquired about the elements of the Romani culture that Poles are best familiar with. There were six suggested answers to choose from, including the option "Other." Multiple answers were allowed. The answers we obtained reveal that songs and dances are most typically associated with Roms, the former indicated by 91 respondents and the latter by 105; 66 mentioned Gypsy traditions. For 18 respondents, Gypsy legends are best known 
to Poles. $4 \%$ of the respondents (6) consider painting as the best-known element of the Romani culture. Three people indicated Romani literature and two respondents mentioned fortune telling (see fig. 11 for question 15).

\section{Which elements of the Romani culture are Poles best familiar with?}

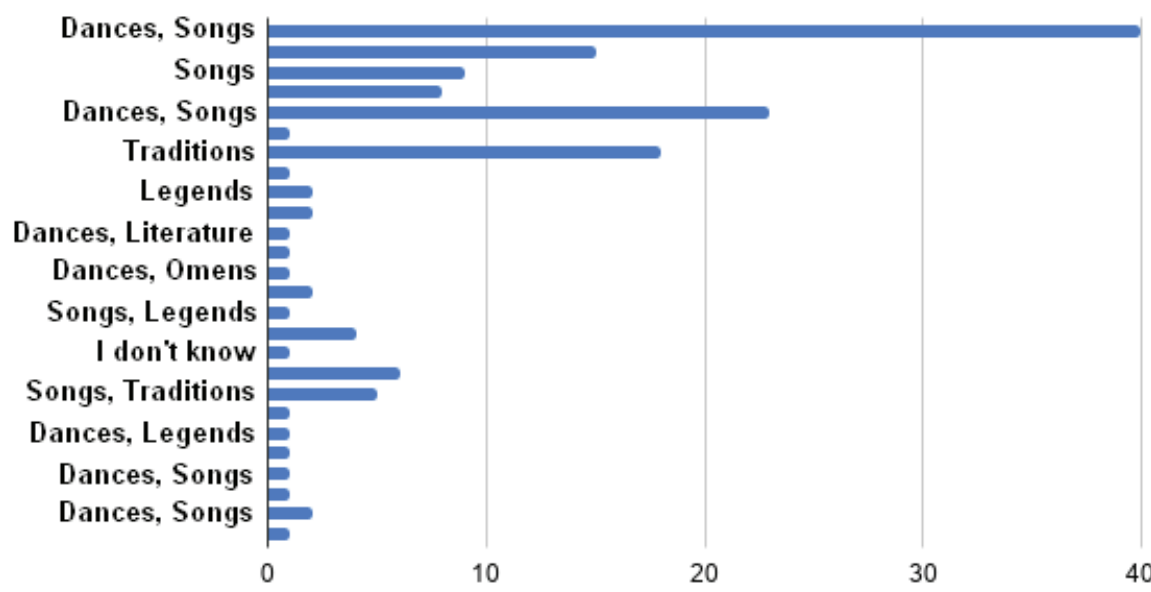

Fig. 11. Question 15: Which elements of the Romani culture are Poles best familiar with?

Poles' attitudes to Roms were addressed by question 16 (fig. 12).

What, in your opinion, is Poles' attitude towards Roms?

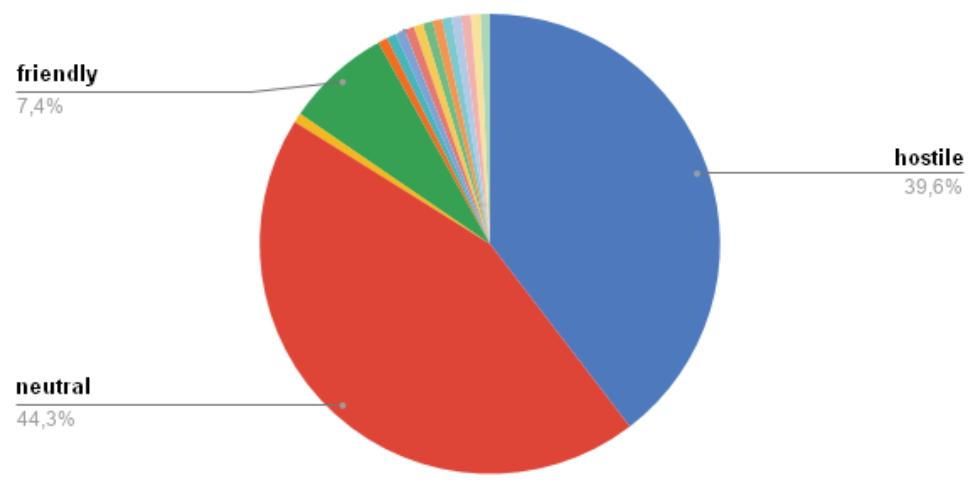

Fig. 12. Question 16: What, in your opinion, is Poles' attitude towards Roms? 
Two options were the most frequently chosen: neutral $(44.3 \%$, red) and hostile $(39.6 \%$, blue). $7.4 \%$ of the respondents consider this attitude as friendly. In individual cases, the answers given were: "suspicious," "deprecating," and "reserved."

In question 17 that followed we asked to specify the respondents' associations with the word Cygan (Gypsy). See fig. 13.

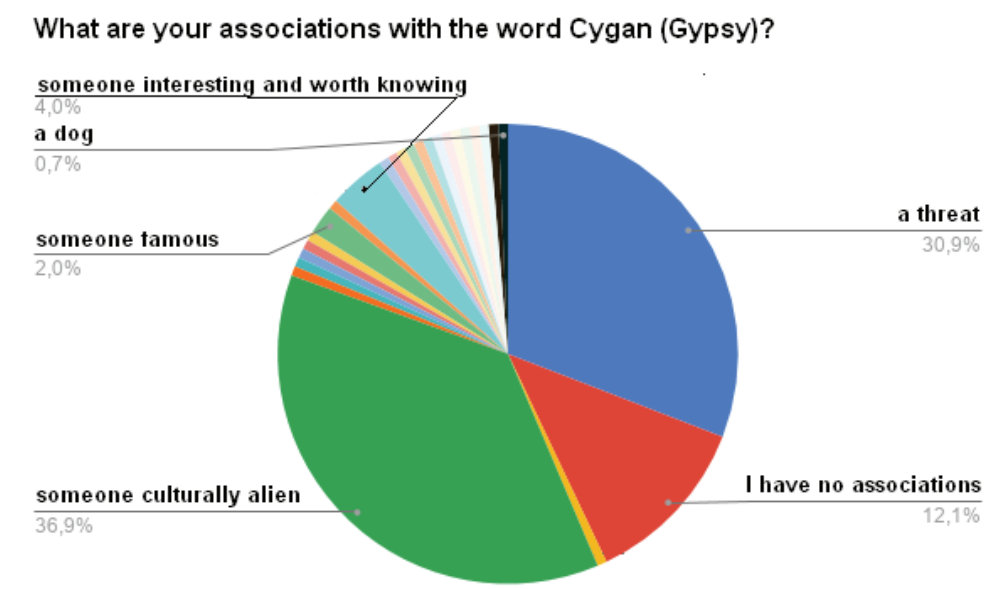

Fig. 13. Question 17: What are your associations with the word Cygan (Gypsy)?

In this question, six possible answers were suggested (including "Other"): "someone culturally alien," "a threat," "someone interesting and worth meeting," "someone famous," and "I have no associations" As depicted in the pie chart, the first answer was the most frequent selection (36.9\%, green). The second most popular choice was that of a threat $(30.9 \%$, blue), while $12.1 \%$ of the respondents had no associations with the word Cygan (red). The answers subsumed under the category "Other" included: someone who is dirty, someone who is trying to cheat you, a thief, a poor person, a migratory merchant, a fortuneteller, conman, an uncivilized person, Jacek Cygan, a dishonest person, theft, misery, and a dog. Two people only indicated that their associations had a rather negative character.

There are a number of stereotypes concerning the perception of different nationalities that function in the Polish society. Hence, we also wanted to identify the most popular stereotypes of Roms. This was the focus of our next question. The respondents were able to choose more than one answer from 5 available options, these being: "Bad experiences in contacts with Roms," 
"They are passed from generation to generation," "Ignorance," "A hostile attitude to anything that is foreign/alien," and "Other." The first answer was selected 87 times, the second option 74 times, the third one was chosen 64 times and 38 people thought that the major source of the stereotypes was Poles' hostile attitude. Under the category "Other," the answer was "I do not know"' (2 respondents).

The next question (no. 19) had a similar structure since the respondents could select more than one answer. It concerned Rom-related stereotypes the respondents were familiar with. Out of the seven answers provided, "vagabond" (włóczęga) scored 94 votes, "fortuneteller" (wróżka) - as many as 101, "singer" (piosenkarz) - 53, "horse-thief" (koniokrad) - 27, "boilermaker" (kotlarz) - 6, and "blacksmith" (kowal) - 2. The answers supplied under the category "Other" included: thief (8), cheater (2), beggar (1), Gypsy (1), and "none of the above" (1).

Question 20 was used to check whether Poles know any famous people or celebrities who are of Romani origin. The list of the names provided together with the number of votes is depicted in figure 14 below.

\section{Which of the people shown below are of Romani origin?}

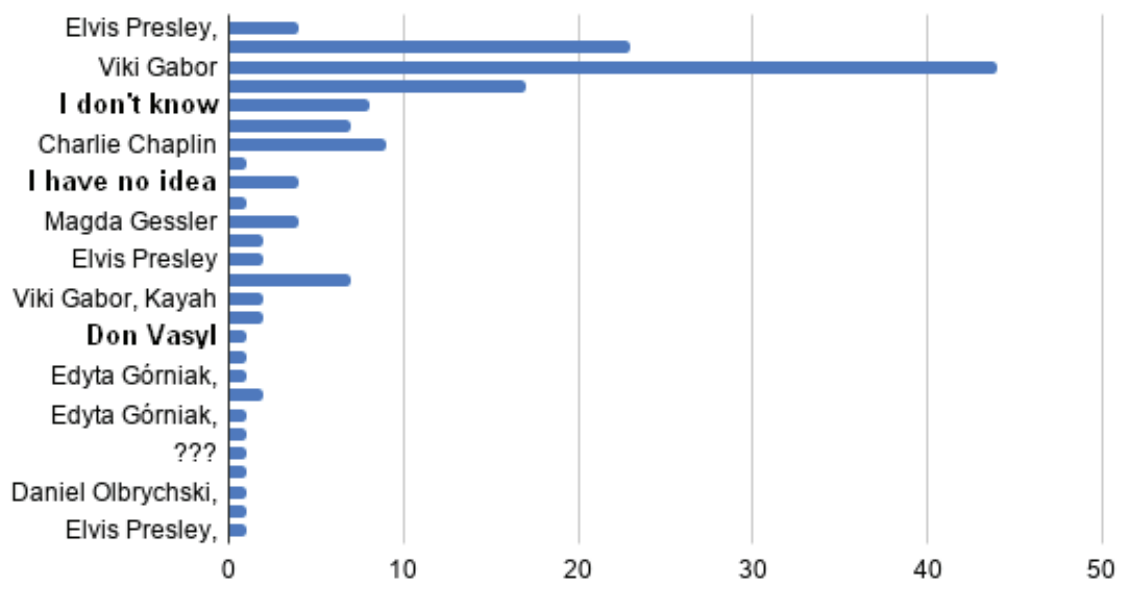

Fig. 14. Question 20: Which of the people shown below are of Romani origin?

The respondents' choices were as follows: Viki Gabor (79), Edyta Górniak (49), Charlie Chaplin (16), Krzysztof Krawczyk (13), Daniel Olbrychski (10), 
Elvis Presley (8), and Magda Gessler (7). The only person who was not chosen was Robert Lewandowski. The respondents extended the list of names by adding Kayah (singer) and Don Vasyl (singer). In 16 cases the answer was "I don't know."

The two final questions addressed the willingness of the respondents to learn more about the Romani culture (no. 21). The last one asked for a brief justification of the opinion stated above.

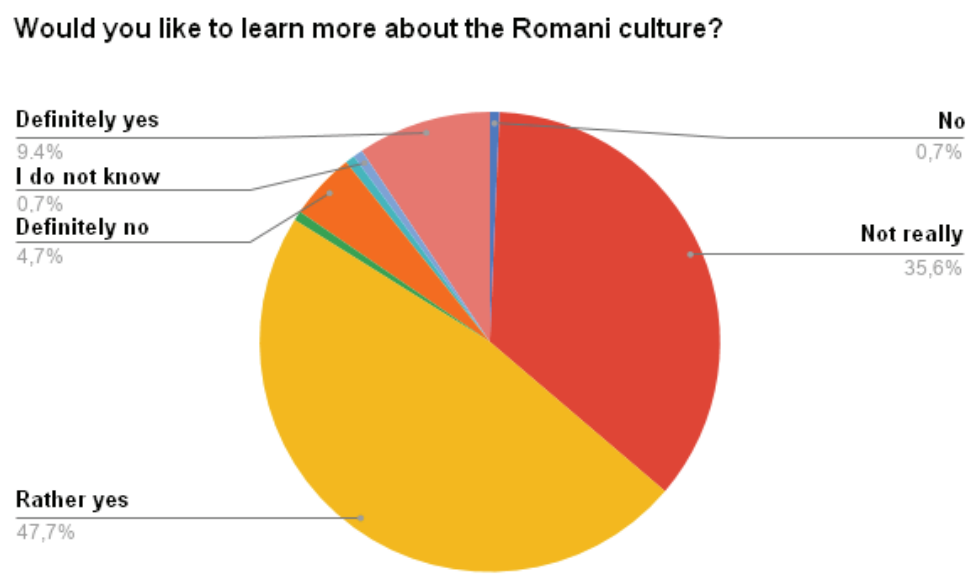

Fig. 15. Question 21: Would you like to learn more about the Romani culture?

The most frequent answer was "Rather yes" (47.2\%, yellow). "Definitely yes" was chosen by $9.4 \%$ (pink), and $0.7 \%$ of the respondents did not know how to answer the question. The answer "Definitely no" was selected by $4.7 \%$, and "Not really" by $35.6 \%$. In the category "Other" one of the answers was plain "No," indicated by $0.7 \%$ of those surveyed. A similar number of people wrote "I wouldn't mind." 114 opinions were given to justify the respondents' choices.

Below, I present a summary of the major reasons specified by the participants.

People would like to learn more about the Romani culture because:

- Broader knowledge counteracts the existing stereotypes

- New knowledge is nothing to be afraid of

- Different cultures are interesting

- Roms show how rich and colorful their culture is

- Broader knowledge helps people better understand the Romani culture

- It is always worth learning about new cultures 
- Broadening one's knowledge of new cultures is an enriching experience, developing one's outlook on life

- Romani traditions are intriguing

- It is desirable to know the culture of people who are our co-citizens

- Roms are lively, joyful, and colorful

- The Romani culture is part of the Polish history

- Each culture is unique

- Cultural diversity helps build social bonds, it introduces new values and teaches respect for other people

- The decline of Roms' culture would impoverish the Polish culture

- The Romani language has evolved in its own unique way, it has borrowed from Polish and its use is conditioned by interesting sociolinguistic factors

- People brought up with stereotypes would have a chance to confront their opinions with facts.

People would not like to learn more about the Romani culture because:

- They do not feel any need to broaden their knowledge in this area

- They had unpleasant experiences with Roms

- They are not interested in the Romani culture

- They are not interested in any culture

- They have different priorities

- They do not like either Roms' dances or their music

- They regard their current knowledge broad enough

- This kind of knowledge does not seem useful

- They consider Roms' culture as weird and alien

- The facts they know about Roms are discouraging

- They are interested in wealthier nations

- They have bad associations with Roms.

In the subsequent section of the article, a detailed discussion and interpretation of the above data will be presented. 


\section{DISCUSSION}

\subsection{Introduction}

At the outset of our discussion, what needs to be emphasized is the anonymous character of the survey by which the above data were collected. It was my intention to enable potential respondents to freely express their opinions, without any time pressure and to obtain as many responses as possible. This rationale justifies the choice of the research strategy (an online questionnaire) guaranteeing both anonymity and the selection of a relatively wide sample of people from a pre-determined population, which in this case was the Polish society. The questionnaire was simple in terms of its form and thus easy to complete. It contains 22 short questions, most of which required the choice of a single answer. Almost in each question the option "Other" was also provided to enable the respondents to express their opinion in case the range of the suggested answers was not sufficient. The survey administered in this way made it impossible for the author to control her potential respondents or any other variables such as allocating the participants into specific groups. The present study falls under the category of descriptive research since the aim of the enquiry was to gather information on the currently prevalent attitudes of Poles to Roms, their culture and language.

Another important aspect of this cross-sectional survey was to describe associations between respondent-specific characteristics (e.g., gender, age, and education) and the attitude adopted. However, the nature of the questions makes it also possible to illuminate specific problems in the field of PolishRomani relations through a more focused data analysis by identifying the effects of the variables mentioned above on the attitudes described by the participants. In this sense, our research can also be perceived as being, at least partly, analytical.

The survey was tested on a pilot sample of Polish citizens consisting of ten family members and friends of the author to make sure that the questions were clearly formulated and interpreted as intended by the researcher. I also checked whether a sufficient number of response categories was available. In the process of data collection, I used a random-sampling technique to maximize the response rate, on the one hand, and to be able to generalize the obtained results to a larger population, on the other.

It has to be admitted that even though the questionnaire was administered online and the potential number of addressees seemed very big, it was hard 
to secure a higher response rate to the survey. Overall, 150 of those were collected. About 1,500 individuals were invited to fill in the questionnaire in the initial stage of its administration. Further, the survey was shared on Facebook, which probably multiplied the number of addressees. Still, we must keep in mind that currently people are bombarded with surveys of different kinds, including political, social, and economic ones. We believe that this fact had a considerable effect on the total number of participants of our study.

The survey included 5 introductory questions concerning gender, age, profession, educational experience, and place of residence of the respondents. Then, 17 Roms-related questions followed, of which 15 were of the closed type and two were open. The major aims of our study were threefold:

a) to establish how much and from what sources Poles know about Roms, their language and culture

b) to identify Poles' attitudes towards Roms, the Romani language and culture

c) to identify the existing stereotypes and their sources.

We also intend to determine possible correlations between the five abovementioned variables and the attitude of the respondent.

\subsection{Analysis of the research results}

The analysis of the respondents' answers to the five opening questions of the survey reveals that the majority of the research participants are women (70.7\%). 72.7\% of the respondents are young people between 19 and 30 years of age. In fact, two third of the sample group are under 50. Almost all the respondents have either secondary or higher education. $88 \%$ of them live in towns and over $50 \%$ in big cities with more than 100 thousand inhabitants. The fact that mostly women filled in the questionnaire does not seem surprising as they are in general more interested in interpersonal relations and are more willing to talk about their feelings and attitudes. Also, there is an expected correlation between one's place of residence and education status.

It is significant that only $13.3 \%$ of the respondents confess to having no knowledge about Roms or Romani-related issues. These are predominantly young people, usually college or school students. Only two people in this group were above 50. The lack of knowledge does not correlate with the gender. We believe that since they had never met any Roms, they had not had any previous experience that their opinion might have been based on. Young people today obtain knowledge most often from the Internet, so it 
was rather unlikely that they should intentionally access any Romani-related websites. Almost $87 \%$ of the respondents have either heard or read about Roms and their culture or gained the knowledge from their personal experience. In fact, conversations with friends and relatives and personal experiences are the two main sources of knowledge indicated by the respondents, of which the former is the most frequently selected from the options provided in the survey. We believe that this fact very well correlates with the variable of gender. Women willingly participate in interpersonal relations as well as exchanges of thoughts and ideas. They, more often than men, regard conversations with others as a good opportunity to obtain new knowledge. Interestingly, $54.7 \%$ of the respondents have talked to a Rom themselves, one fifth of them might have, as they selected the option "I do not remember," whereas only $18.7 \%$ never had such an experience. Thus, more than a half of the participants had an opportunity to both learn about and develop a specific attitude to Roms on the basis of their personal experience. The type of experience itself, as revealed by the survey, was, in most cases, a reaction to a fortune-telling proposal made by a Gypsy (40.7\%). A similar percentage will be obtained when we sum up votes for a friendly conversation and traditional greeting. It is likely that contacts of that kind occur when people are close neighbors. If this was the case, we might conclude that personal contacts of Poles with Roms are of either neutral or positive character. This intuition might be supported by the fact that only $5.4 \%$ of the respondents indicated that their contact with a Gypsy was a quarrel.

As for the kind of knowledge that Poles have about Romani-related problems, with respect to the size of this community, their estimates are quite correct. $93.3 \%$ of the respondents think it is small or negligible. Recall that the size of the Gypsy community in Poland is between 20 and 30 thousand, which is less than $1 \%$ of the country's population. When asked about the places where Roms live, the respondents are definitely less certain. More than a half of them have no idea which regions of Poland the Romani people inhabit. $34 \%$ of the participants know some of these sites. We predict that, in most cases, these are at the same time the places of the respondents' residence. The Romani language was never heard by $16 \%$ of the respondents, the other people heard it at least once or might have heard it. The majority of the survey participants find it similar to Romanian (56.7\%), a considerable number to Hungarian (20\%) and only 5 people to Polish. Romani belongs to the Indo-Aryan group and differs from the languages listed as possible responses. However, an average Pole does not have any exact linguistic knowledge 
of language families and the responses indicated in the questionnaire should be treated as subjective perceptions. The similarity between Romani and Polish could be caused a considerable number of Polish borrowings in the language spoken by Roms. Also, unsurprisingly, the respondents knew very few words of Romani.

$42.7 \%$ of the survey participants notice some contribution of Roms to the culture of Poland, which is two times more than those who think the opposite. One third of them admit to having no sufficient knowledge in that area. Roms' songs, dances and traditions are the best-known elements of the Romani culture and this explains the fact that the majority of the famous Roms in question 15 were correctly identified by the respondents.

The attitudes of Poles towards Roms are closely connected both with their personal experiences and stereotypes associated with Gypsies. 39.3\% of the respondents describe this attitude as hostile, while only $7.3 \%$ as friendly. $44 \%$ indicated the option "Indifferent." When asked about their associations with the word Cygan, they selected "threat" and "someone culturally alien," which can derive from the fact that Roms rarely integrate themselves with the community they live in, trying to preserve their own identity. Those who picked "threat" (30.7\%) might have based their choice on their own bad experiences with Roms. This reason was indicated as the major cause of Gypsy-related stereotypes by 87 respondents. The other frequent causes were ignorance and inheriting them from the older generation. The most popular stereotype of a Gypsy was a fortuneteller (102 responses), the second was a tramp (95), and the third - a singer (54). These three popular stereotypes are closely connected with the Roms' migratory lifestyle and traditional occupations. What is noteworthy, over $57 \%$ of the respondents would like to find out more about the Romani culture, compared to $5 \%$ of those who say a definite no. The people who said they would not or rather wouldn't want to learn more about Roms mostly justified their choice as following from the lack of interest. Those who said yes to that idea, expressed the need to know better the culture of their co-citizens, fascination with the Gypsies' colorful traditions and the necessity to overcome the existing stereotypes.

\section{CONCLUSION}

Beyond doubt, cultural diversity has the potential to enrich both individual and social life of people. Throughout ages, Poland was the place where different 
cultures cohabited, met, and frequently merged. Since the fourteenth century, the Romani culture has been present in various parts of Poland. However, Roms, unlike Jews, Ukrainians, or Lithuanians for instance, would not settle down or integrate with local communities. Their unique identity and the need for independence and migratory lifestyle would often meet with little understanding or even hostility. That led to the development of stereotypes which persisted in time and nowadays are hard to eradicate. This article presents the results of the questionnaire-based research in the context of Polish-Romani relations as they developed throughout ages. The analysis of the survey results was preceded by a description of the Romani culture and language which constituted the background of the study. The research revealed that the majority of Poles know and appreciate the Romani traditions, but their knowledge of the Romani language is next to none. Though the society seems to be divided in terms of people's attitude towards Roms, more Poles, young ones in particular, are willing to learn more about this community than those remaining either hostile or indifferent.

\section{WORKS CITED}

Boretzky, Norbert. Die Vlach-Dialekte des Romani. Strukturen - Sprachgeschichte -Verwandtschaftsverhaltnisse - Dialektkarten. Harrassowitz Verlag, 2003.

Crofton, Henry T. "Supplementary Annals of the Gypsies in England before 1700." Journal of the Gypsy Lore Society, new series, vol. 1, 1907-1908, pp. 31-34.

Ficowski, Jerzy. Cyganie na polskich drogach. Wydawnictwo Literackie, 1985.

"Język romski." Wikipedia, pl.wikipedia.org/wiki/J\%C4\%99zyk_romski\#Dialekty. Accessed 4 April 2020.

Kluge, Friedrich. Rothwelsch, Quellen und Wortschatz der Gaunersprache. K. J. Trübner, 1901.

Kopańska, Justyna. Życie w dwóch światach. Dylematy tożsamościowe Cyganów (Romów) w Polsce. Unpublished MA thesis. Łódź, 2008.

Kowarska, Agnieszka. Polska Roma - tradycja i nowoczesność. Wydawnictwo DIG, 2005.

Krzyżanowski, Piotr. “Akcja osiedleńcza ludności cygańskiej w PRL.” Dialog-Pheniben, no. 2, 1996, p. 13.

Matras, Yaron. Romani: A Linguistic Introduction. Cambridge UP, 2002.

Mirga, Andrzej, and Lech Mróz. Cyganie. Odmienność i nietolerancja. Wydawnictwo Naukowe PWN, 1994.

"Postrzeganie Romów, języka oraz kultury romskiej w Polsce." Google Forms, 13 March 2020, docs.google.com/forms/d/e/1FAIpQLSd0HEtX0NOmAoZOSHXmx6TAjrQTXv12DAVo1m vJTqG4AG9qew/viewform?usp=sf link.

"Romskie dialekty/Romani." Dziedzictwo językowe Rzeczypospolitej: Baza dokumentacji zagrożonych języków, www.inne-jezyki.amu.edu.pl/Frontend/Language/Details/25. Accessed 4 Apr. 2020. 
Sampson, John. The Dialect of the Gypsies of Wales. Clarendon Press, 1926.

Ustawa z dnia 6 stycznia 2005 o mniejszościach narodowych i etnicznych oraz o języku regionalnym (Dz. U. Nr 17, poz. 141, z późn. zm.), mniejszosci.narodowe.mswia.gov.pl. Accessed 10 Apr. 2020.

Wagner, Peter. 2012. A Grammar of North West Lovari Romani Gramatika severozápadni olaštiny (lovárštiny). PhD dissertation, Faculty of Arts (FF), Univerzita Karlova v Praze, 2012.

\section{MIEJSCE JEZYKA I KULTURY ROMÓW W POLSCE. SPOSTRZEŻENIA NA BAZIE ANKIETY}

\section{Streszczenie}

Celem artykułu jest prezentacja najważniejszych informacji dotyczących kultury Romów i języka romskiego w Polsce. Przedstawiona analiza oparta jest na wynikach ankiety przeprowadzonej przez autorkę wśród Polaków posiadających konto na Facebooku. Opis badania poprzedza wnikliwa dyskusja najistotniejszych elementów kultury romskiej oraz wydarzeń historycznych, które ukształtowały współczesne oblicze tej społeczności. Artykuł zawiera także charakterystykę języka romskiego, który bardzo różni się od polszczyzny. Celem przeprowadzonego badania było określenie stosunku Polaków do Romów, ich języka i kultury, odkrycie popularnych stereotypów, które funkcjonują w społeczeństwie polskim oraz próba odkrycia ich źródeł. Wiedza ta może bowiem w istotny sposób pomóc w budowaniu pozytywnych relacji między Polakami i Romami.

Słowa kluczowe: język romski; kultura; historia; stereotypy; wielokulturowość. 